KATARZYNA ZIELIŃSKA, JANINA JAKUBOWSKA-GABARA, JEREMI KOŁODZIEJEK

Department of Geobotany and Plant Ecology, University of Łódź, Banacha 12/16, 90-237 Łódź, Poland, kziel@biol.uni.lodz.pl

\title{
ADAPTATION OF THE “HERBARIUM” COMPUTER DATABASE TO ARCHIVING AND ANALYSIS OF FLORISTIC DATA
}

\begin{abstract}
The aim of the study was to present "Herbarium" computer database. The basic goal of construction of the database was gathering and analysing of archival and contemporary floristic data referring to the area of Central Poland. Registered information considers the stands and characteristic biological and ecological traits of particular taxa. Life forms, indices of ecological requirements, the phytogeographical elements, protection and threat status are among them. The database enables the presentation of geographical distribution of taxa in the area of Central Poland with the cartogram method based on the grid of $2 \mathrm{~km}^{2}$ according to the Distribution Atlas of Vascular Plants in Poland (ATPOL).
\end{abstract}

Key words: database, floristic data, cartogram method, Central Poland

\section{INTRODUCTION}

Since the first floristic research conducted in Central Poland in the 19th and at the beginning of the 20th century, particular plant species have been identified in that area by next generations of botanists. The data thus collected, varying in the degree of detail and accuracy, has been included in both published and unpublished works, as well as in scientific notes from field work. The term Central Poland refers to the area situated in the central part of the country, as earlier specified by: OLACZEK (1974), Mowszowicz (1978), KUROWSKi (1986), JAKUBOWSKA-GABARA, PisAREK (1997), JAKUBOWSKA-GABARA (2005) and JAKUBOWSKA-GABARA et al. 
(2009). A great deal of floristic data has been documented in herbarium collections compiled in Herbarium Universitatis Lodziensis (LOD). Further information, regarding approximately 1600 species of vascular plants found in that area, has been provided owing to long-term research, rich literature and herbarium collections (JAKUBOWSKA-GABARA 2005; JAKUBOWSKA-GABARA et al. 2009). Yet, what is clearly missing is any data compilation specifying the geographical distribution of the plant species in that area and changes in the distribution over time. Such compilation is a key element in dealing with a vast number of phytogeographical problems and is also a valuable source of information on biodiversity protection.

A great deal of the scattered data requires unification and compilation into one data collection. Contemporary computer techniques allow such data compilation and processing. What is more, computerized information systems that can store and quickly retrieve even large amounts of data are becoming more widespread, especially in the field of floristic cartography (FALIŃSKI 1990). In 2003, by a special order of the Department of Geobotany and Plant Ecology of the University of Łódź a floristic database called "Herbarium" was designed and constructed. The database provides a wide spectrum of possibilities of collecting data on plant stands, together with any information regarding the biological and ecological characteristics of particular species. To a large extent, all the strong points of the database result from a good co-operation and numerous consultations between the botanists of the SubDepartment of Plant Systematics and Geography and computer programmers. The "Herbarium" database has been constructed in the Linux System, characterized by low-failure frequency and wide accessibility. The system also enables adjusting the current database to its new, improved version, without losing any previously entered data.

\section{DATABASE AIMS AND USE}

The main aim of a database construction is the archiving of data. It has been assumed that the "Herbarium" database will store both the archival and contemporary data regarding particular plant species in the area of Central Poland. Two methods have been employed to collect the data: descriptive research and the 
cartogram method. A grid of basic squares $2 \mathrm{~km}$ by $2 \mathrm{~km}$ based on the ATPOL grid (ZAJĄC 1978) has been applied. Therefore, the floristic data presented in the cartogram can be easily and thoroughly incorporated into ATPOL (Distribution Atlas of Vascular Plants in Poland). The cartogram thus prepared enables establishing precise locations of particular plant species. The cartogram presented in this paper displays the main rivers in the area of Central Poland: the Bzura, the Pilica and the Warta (Fig. 1).

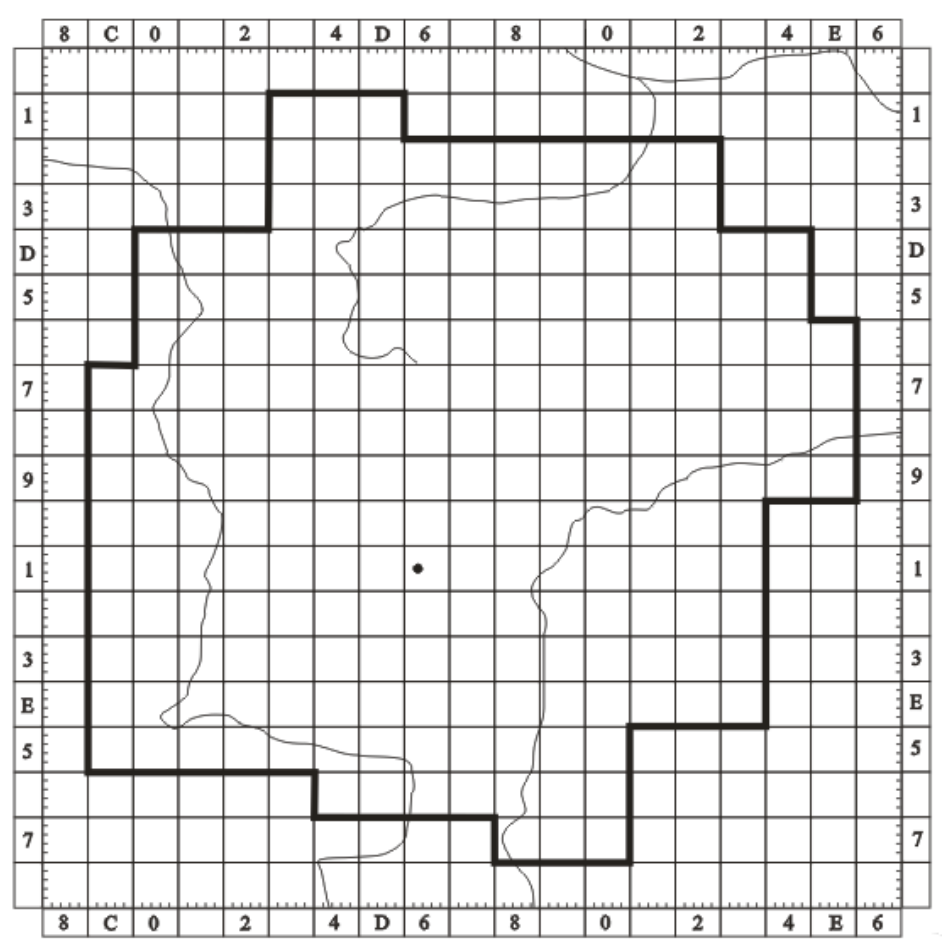

Fig. 1. Area of Central Poland in the ATPOL grid (according to ZAJAC 1978) and an example of a locality (dot) in square DE1621: DE - symbol of a $100 \mathrm{~km}^{2}$ square, 16 - symbol of a $10 \mathrm{~km}^{2}$ square, 21 - symbol of a $2 \mathrm{~km}^{2}$ square.

The "Herbarium" database enables both graphical and tabular representation of data. The latter proves useful while specifying the source data of particular plant species.

One of the key characteristics of the database is the possibility of entering data from different sources. The floristic data is incorporated into particular data 
category based on herbarium collections, as well as published and unpublished data. As for the latter, the author, the title and the year of publication (or the year it was written) are noted. With herbarium collections the catalogue number of a given collection is also specified.

As mentioned before, the "Herbarium" database offers information on the location of particular species, but it archives data on species richness and habitats as well. It also makes it possible to specify by whom the individual species have been registered, labeled and their taxonomic group defined. Thus, an archive offering the most comprehensive information possible on herbarium collections and the species composition of Central Poland flora is being constructed. The data collected in the "Herbarium" database is not only available for contemporary research, but can also prove crucial and adequate to future researchers.

Another aim behind constructing such a database is to analize the collected floristic data regarding the characteristics of particular species. Each species is characterized by a specified set of traits, defined with the use of available species classifications, such as Raunkiaer's life-form classification (RAUNKIAER 1934), species division into geographical-historical groups by KoRNAŚ (1968) and a set of ecological indicator values (ELLENBERG et al. 1992; ZARZYCKI et al. 2002). Legal protection status of individual species and their category of threat have also been determined. Moreover, the database is equipped with a report designer function that allows of any given combination of data that needs to be collected. To give an example, it's possible to retrieve data on the list of species found in the wetlands, under strict protection and registered in DE 3444 square in the 90s of the 19th century. The database has been constructed in such a manner that all possible ways of analysis of the data collected therein are possible.

The "Herbarium" database may also prove useful in evaluating projects that could affect the environment, or in opinionating special development plans. Besides, it can be used to help prepare proposals for enforcing protection laws in areas of valuable nature, to make reports on nature condition and red lists of threatened species and habitats of a given region. At present, the database consists of approximately 140000 data items regarding vascular plant species, including those 
registered in the Distribution Atlas of Vascular Plants in Poland (ZAJĄC A., ZAJĄC M. 2001).

\section{REFERENCES}

Ellenberg, H., Weber, H.E., Düll, R., Wirth, V., Werner, W., Paulissen, D. 1992. Indicator values of plants in Central Europe. Scripta Geobotanica 18: 1258.

FALIŃSKI, J.B. 1990. Kartografia geobotaniczna. Cz. 1. Zagadnienia ogólne, kartografia florystyczna i fitogeograficzna. PPWK im. E. Romera, WrocławWarszawa, pp. 1-284.

Jakubowska-Gabara, J. 2005. Vascular Flora of Central Poland - Diversity, Changes, Threats. Biodiversity in Relation to Vegetation Zones in Europe, In: K. CZyŻEWSKA, J. HEREŹNIAK (eds), University of Łódź Press, Łódź, pp. 19-30.

JAKUBOWSKA-GABARA, J., PisAReK, W. 1997. Materiały do flory naczyniowej Polski Środkowej. Fragm. Flor. Geobot., ser. Polonica 4: 9-15.

JakUBOwsKa-Gabara, J., WitosŁawski, P., ZieliŃSKA, K. 2009. Flora naczyniowa - różnorodność, zmiany, zagrożenia. In: J.K. Kurowski (ed.), Szata roślinna Polski środkowej. Towarzystwo Ochrony Krajobrazu, Wydawnictwo EKOGRAF, Łódź, pp. 57-80.

KORNAŚ, J. 1968. Geograficzno-historyczna klasyfikacja roślin synantropijnych. Mat. Zakł. Fitosocj. Stosow. UW, Warszawa-Białowieża 25: 33-41.

KUROWSKI, J.K. 1986. Ocena stanu ochrony flory w rezerwatach przyrody Polski Środkowej. Acta Univ. Lodz., Folia Sozol. 3: 205-224.

Mowszowicz, J. 1978. Conspectus florae Poloniae Medianae (plantae vasculare).

Przegląd flory Polski Środkowej (rośliny naczyniowe). Wydawnictwo Uniwersytetu Łódzkiego, p. 395.

OlaczeK, R. 1974. Materiały do flory Polski Środkowej. Zesz. Nauk. UŁ, Ser. II, 54: 27-39.

Raunkiaer, C. 1934. The Life Forms of Plants and Statistical Plant Geography. Oxford University Press, Oxford, p. 632. 
ZAJĄC, A. 1978. Założenia metodyczne Atlasu rozmieszczenia roślin naczyniowych w Polsce. Wiad. Bot. 22: 145-155.

ZajĄC, A., ZajĄC, M. (eds) 2001. Distribution Atlas of Vascular Plants in Poland. Atlas rozmieszczenia roślin naczyniowych w Polsce. Instytut Botaniki UJ, Kraków, pp. 1-715.

Zarzycki, K., Trzcińska-Tacik, H., RÓżAŃski, W., SzeląG, Z., WoŁeK, J., KORZENIAK, U. 2002. Ecological indicator values of vascular plants of Poland. Ekologiczne liczby wskaźnikowe roślin naczyniowych Polski. Instytut Botaniki im. W. Szafera PAN, pp. 1-183. 